\title{
Prevention Policy in Controlling Narcotics Circulation in Cirebon Detention Center
}

\section{Suwirno}

Faculty of Law, University of 17 Agustus 1945 Cirebon, Indonesia. E-mail: suwirno@untagcirebon.ac.id

\begin{tabular}{l}
\hline ARTICLE INFO \\
\hline Keywords: \\
Implementation of Policies, \\
Legal Culture, Legal \\
Structure, Legal \\
Substance, Narcotics \\
Circulation. \\
How to cite: \\
Suwirno, Prevention \\
Policy in Controlling \\
Narcotics Circulation in \\
Cirebon Detention Center \\
JURNAL MEDIA \\
HUKUM, +62 274 \\
387656 (Ext. 220) \\
Article History \\
Received: 04/04/2019 \\
Reviewed: 26/06/2019 \\
Revised: 27/06/2019 \\
Accepted: 29/06/2019 \\
\end{tabular}

\begin{abstract}
The lack of control from the authority has opened the opportunity for the prisoners to do transaction of narcotics in the prison. Circulation of narcotics in the prisons involves complex networks. The paper aims to explore how the implementation of policies in preventing narcotics circulation in the class I Cirebon Detention Center is and how preventive construction is in handling the circulation of narcotics in the class I Cirebon Detention Center in Jalan Benteng, Cirebon City, West Java. The policies are made to prevent narcotics circulation in Cirebon Detention Center. The research was carried out through both library-based study and field work. From the research, it is found that the legal system needs to be improved in order to solve the problems of narcotics circulation in Cirebon Detention Center. The improvement is necessary to all aspect of legal system, namely: legal substance, legal structure, and legal culture.
\end{abstract}

DOI: 10.18196/jmh.20190125

Copyright (C) 2018 MEDIA HUKUM. All rights reserved.

\section{Introduction}

The Ministry of Law and Human Rights said that the number of narcotics addicts detained at Penitentiary and Prison Houses in Indonesia is increasingly swollen. The latest data from the Directorate General of Penitentiary states that the number reaches 46,000. Meanwhile, of the approximately 259,000 prisoners in 522 prisons and remand centers, 115,000 of them are prisoners involved in drug cases. This condition continues to make prisons and detention centers overcapacity. In fact, according to the Narcotics Law, it has been mandated that drug users should be rehabilitated medically or socially. ${ }^{1}$

1https :/ / kabar24.bisnis.com/read/20190218/16/890332/peredaran-narkoba-di-lembaga-pemasyarakatan -signaled-strengthen 
Narcotics Penitentiaries as a Special Correctional Institution for Narcotics which intended for drug convict cases, are independent and must have different patterns of coaching than public Correctional Institutions. There are two aspects of handling and approach used by Correctional Institutions for drugs abusers, namely the care and health of prisoners. It is good for users and dealers who actually are also users. ${ }^{2}$

The availability of super tight security equipment such as X-rays, metal detectors, and jammers (cellular telephone breakers from outside and inside the LP) installed in some public LPs, is not an accurate solution for fostering users and combating drug trafficking. ${ }^{3}$

Drug trafficking in Cirebon is at an alarming rate. Almost every day the police arrest narcotics syndicates, especially for marijuana. From many drug cases revealed by the police, the Narcotics Investigation Unit of Cirebon Police mostly carried out the raids. Cirebon is included in the first serial number of disclosed narcotics cases.

Cirebon has the Cirebon Correctional Institution for Narcotics Class II, a place to provide guidance to prisoners and correctional students and accommodate prisoners involved in narcotics cases.

Nowadays the existence of Penitentiary Institutions has been contaminated with the circulation of illicit narcotics goods. Penitentiary institutions have been used as a narcotics business place by inmates. Being behind bars does not make the drug kingpin stop distributing illicit goods. Drug purchasing transactions and negotiations can still be carried out by these prisoners. Detention Center (Lapas) was blamed, as the most responsible party because of the weak supervision in prisons.

The National Narcotics Agency issued a statement earlier this year that most narcotics dealers in Indonesia controlled their businesses from prisons with cellphone. This is not really surprising given the high number of drug prisoners. Based on official data from the Ministry of Law and Human Rights, until March 2018, there were 51,130 people jailed for drug abuse or crimes. Half of that amount, 24,568 were distributors and the rest were users. ${ }^{4}$

This shows that narcotics abuse in Indonesia has reached a very alarming level, especially in Lapas. This condition is strengthened by a statement from the President of the Republic of Indonesia that almost 50\% of drug trafficking in Indonesia occurs and is controlled from inside the Penitentiary (Lapas) and State Detention House (Detention Center) ${ }^{5}$ and the number of prisoners and prisoners of narcotics cases as of April 2016 reached 80,360. ${ }^{6}$

With the placement of drug prisoners in a special prison and handled by social workers who are trained intensively, it is certain that it will grow a commitment to participate in fostering and combating drug trafficking which is increasingly prevalent in public lapas. This seems to be a solution that can reduce the fatal effects of the rampant drug business.

Guidance for prisoners (prisoners) in correctional institutions (prisons) and state detention centers will not work well if prisons/detention centers are not orderly. Regarding to the proliferation of narcotics users and dealers, for those caught by the authorities, prisons are the impact of direct action that must be received by users and distributors. The circulation of narcotics and illegal drugs in the form of marijuana and methamphetamine are still prevalent in the city of Cirebon. Of the many drug cases, dealers are the most revealed parties. During 2012, the disclosure of drug cases rose by $20 \%$. The District Prosecutor's Office of Cirebon City

\footnotetext{
2 prison narcotics .wordpress.com

${ }^{3}$ Ibid.

${ }^{4}$ www.bbc.co.uk/indonesia/130711_lapsus_korupsi_drugs.html.July 11, 2017.

5 http://pedomanbengkulu.com/2016/03/50-peredarannarkotika-dikontrol-dari-lapas/, (accessed April 5, 2017).

${ }^{6}$ Data from the Director General of Corrections of the Ministry of Law and Human Rights.
} 
destroyed 65 grams of dried marijuana leaves and 3.5 grams of methamphetamine on the Kejari yard in Cirebon City. ${ }^{7}$

Illegal circulation of narcotics in prisons is carried out without rights or against the law. ${ }^{8}$ It shows that narcotics in prisons is an extraordinary crime with a very complex network system, for example transactions conducted in a large-scale of narcotics networks are done with various modes, such-as smuggling, to online gambling or online transaction. This condition has a role so that it has an impact on the negative view of society towards the implementation of law enforcement in the Penal Institution environment.

The research problems are: (1) how is the implementation of policies in preventing of narcotics circulation in the class I Cirebon Detention Center? (2) How does preventive construction handle the circulation of narcotics in the class I Cirebon Detention Center in Jalan Benteng, Cirebon City, West Java? The purposes of the research are to find out the implementation of policies in preventing narcotics circulation in the class I Cirebon detention center and to know how preventive construction handles the circulation of narcotics in the Class I Cirebon Detention Center in Jalan Benteng, Cirebon City, West Java.

\section{Method}

The methods used in this research are study of literatures (library research) and field research. Literature study (library research), is an inquiry through literature and a variety of reading materials by examining theories that exist in the legal literature about narcotics crimes, and fostering prisoners. Field research (field research), ${ }^{9}$ is a study that requires writers to go directly to the field or object of research in order to obtain data relating to research.

\section{Analysis and Result}

\subsection{Implementation of Policies in Combating Narcotics Circulation}

Provisions regarding the rehabilitation of narcotics addicts and victims of narcotics abuse have been regulated in Law Number 35 of 2009 as well as previous laws, namely Law Number 22 of 1997, as for other policies that support the rehabilitation of narcotics addicts by issuing a Letter Circular of the Supreme Court (SEMA) Number 04 of 2010 which is a revision of the Supreme Court Circular Number 07 of 2009, Government Regulation Number 25 of 2011 concerning the Required Policy to Report Narcotics Addicts and Victims and the latest policies issued by the Chair of the Supreme Court of the Republic of Indonesia Minister of Law and Human Rights of the Republic of Indonesia, Minister of Health of the Republic of Indonesia, Social Minister of the Republic of Indonesia, Attorney General of the Republic of Indonesia, Head of National Police of the Republic of Indonesia, Head of the National Narcotics Agency of the Republic of Indonesia on "Handling Narcotics Addicts and Narcotics Abuse Victims Narcotics Into Rehabilitation Institutions" based on the consideration that:

a. The number of Narcotics Addicts and victims of Narcotics Abuse such as Suspects, Defendants, or Prisoners in Narcotics Crime are increasing and the treatment and/or treatment efforts have not been carried out optimally and integrated.

b. Explanation of Article 21 Paragraph (4) Letter b of Act Number 8 of 1981 concerning the Criminal Procedure Code, states that the suspect or Defendant Narcotics addict as far as possible is detained in a certain place which is also a place of care; ${ }^{10}$

\footnotetext{
7 http:/ / www.seputar-indonesia.com

8 Law Number 35 of 2009 concerning Narcotics, Article 1 number 6

9 Soekanto, S and Mamudji, S. (2006). Penelitian Hukum Normatif. Jakarta: Raja Grafindo Persada, p.45.

10 Soesilo, R. (1996). Kitab Undang-undang Hukum Pidana (KUHP) serta Komentar-Komentarnya Lengkap Pasal demi Pasal. Bogor: Politeia, p.22.
} 
c. To restore and/or develop physical, mental, and social condition of suspects, defendants, or inmates in Narcotics Crime, an integrated and coordinated treatment, care and recovery program need to be carried out;

The objectives of the issuance of a joint regulation concerning the Handling of Narcotics Addicts and Narcotics Abuse Victims into Rehabilitation Institutions are:

a. Realizing optimal coordination and cooperation in solving Narcotics problems in order to reduce the number of Narcotics Addicts and Narcotics Abuse Victims such as suspects, defendants or prisoners, through treatment, care and recovery programs while carrying out the eradication of illicit narcotics;

b. Becoming technical guidelines in handling Narcotics Addicts and Victims of Narcotics Abuse as suspects, defendants, or prisoners to undergo medical rehabilitation and/or social rehabilitation;

c. The implementation of medical rehabilitation and social rehabilitation processes at the level of investigation, prosecution, trial and punishment is synergistic and integrated.

Law Number 35 of 2009 concerning Narcotics has guaranteed the efforts of medical rehabilitation and social rehabilitation for addicts and victims of narcotics abuse. This medical and social rehabilitation are intended for narcotics addicts and victims of narcotics abuse not for the distributors. The government's efforts are stated in Article 54 of Law Number 35 of 2009 concerning narcotics, which states that narcotics addicts and victims of narcotics abuse must be medically and socially rehabilitated.

Rehabilitation is a process of integrated medical activities to free addicts from drug addiction. ${ }^{11}$ The medical rehabilitation process includes assessment, preparation of rehabilitation plans, outpatient or inpatient rehabilitation programs and post-rehabilitation programs. ${ }^{12}$ Hospitalization in accordance with the rehabilitation plan has been prepared taking into account the results of the assessment which includes medical intervention. Medical interventions include detoxification programs, symptomatic therapy, and/or medical maintenance therapy, and therapy for complications. Psychosocial interventions are carried out through narcotics addiction counseling, motivational interviews, behavioral and cognitive therapy, and prevention of recurrence. Hospitalization includes medical interventions through detoxification, symptomatic therapy, and treatment of complications. Psychological interventions, among others, through individual, group, family or vocational counseling.

Rehabilitation for narcotics addicts is carried out with the intention to restore and/or develop the physical, mental and social abilities of the sufferer concerned. Medical rehabilitation is a process of integrated medical activities to free addicts from narcotics dependence. ${ }^{13}$ Social rehabilitation is a process of integrated recovery activities, both physical, mental and social, so that former narcotics addicts can return to carrying out social functions in community life.

Medical rehabilitation of narcotics addicts is carried out in hospitals designated by the Minister. In addition, certain rehabilitation institutions organized by government agencies such as Narcotics Prisons and Regional Governments can carry out medical rehabilitation for narcotics abusers after obtaining ministerial approval. Thus for medical rehabilitation for narcotics addicts syringe users can be given a series of therapies to prevent virus transmissions, including transmission of HIV/AIDS through syringes with close supervision by the Ministry

11 Purnamasari, A. (2013). Skripsi: Tinjauan Kriminologis Terhadap Tindak Pidana Peredaran Narkoba di dalam Lembaga Pemasyarakatan Klas I Kota Makassar, Makassar: Fakultas Hukum Universitas Hasanuddin, p. 45 .

12 Sujono, A.R. and Daniel, B. (2011). Comments \& Discussion on Law Number 35 of 2009 concerning Narcotics, Sinar Grafika, Jakarta, p. 23.

13 Mariani, Y.T. (2008). Pengantar Hukum Indonesia. Jilid 4. Jakarta: Sinar Grafika, p. 43. 
of Health. Likewise for the public, they can carry out medical rehabilitation for narcotics addicts after obtaining approval from the minister.

Apart from medical treatment and/or rehabilitation, healing narcotics addicts can be carried out by government agencies or the community through religious and traditional approaches. Whereas social rehabilitation for former narcotics addicts can be carried out by government agencies or by the community.

There are two stages of drug rehabilitation that must be undertaken. First is the stage of medical rehabilitation (detoxification) as the process of addicts stopping drug abuse under the supervision of a doctor to reduce withdrawal symptoms (sakau). The second stage is the stage of non-medical rehabilitation with various programs in rehabilitation places, such as Therapeutic Communities (TC), 12-step programs and others.

Medical rehabilitation is a process of integrated medical activities to free addicts from drug addiction. Medical rehabilitation is carried out on narcotics abusers who have experienced a very high level of narcotics dependence. This high dependence is marked by the urge to use narcotics continuously with increasing doses to produce the same effect. If stopped, it will cause psychological symptoms for the addict. This medical rehabilitation is an attempt to eliminate the dependence of an addict on narcotics. The stage that must be followed by a narcotics addict who will undergo medical rehabilitation is:

a. Detoxification is the process of removing narcotics in the body of drug users. The detoxification process for narcotics addicts is carried out in stages, long and the number of times this detoxification process depends on the amount of narcotics in the body of an addict.

b. Community therapy is a therapy by forming addict groups and groups of addiction counselors, where the appointed addiction counselors are former drug users who have been trained to guide addicts who undergo rehabilitation.

Social rehabilitation is an integrated process of recovery activities, both physical, mental and social, so that former narcotics addicts can return to carry out social functions in people's lives. Social rehabilitation is carried out by rehabilitation institutions formed by the provincial national narcotics agency (BNNP) and some are established based on the community who want to establish a rehabilitation institution. This community rehabilitation agency is under the supervision of the provincial national narcotics agency, social services, and also the health department. In this place of rehabilitation, addicts undergo various programs including therapeutic communities (TC), 12 steps (twelve steps), religious approaches, etc.

Post-rehabilitation/after-care stage is to provide maximum results in the rehabilitation of narcotics addicts from the provincial national narcotics agency. It forms a post-rehabilitation section with the aim that it is easier for former narcotics addicts to return to the society. An example of Post-rehabilitation activities formed by BNNP is by forming "damping" houses as a place to provide assistance to former addicts and victims of narcotics abuse. The "damping" house here provides vocational skills for ex-addicts so they have the skills. At this stage, addicts are given activities in accordance with their interests and talents to fill in their daily activities, addicts can return to school or work but remain under supervision.

This problem of nafza (narcotics and other addictive substances) is a psychiatric problem, not just physical pain, mental healing is more important. Many narcotics patients can recover quickly medically, but mentally they still have a desire to consume narcotics, besides the desire or determination to want to recover from the most important addicts.

The implementation of rehabilitation of addicts and victims of narcotics abuse is guaranteed by law, where the determination of rehabilitation of addicts and victims of narcotics abuse can be done in two ways, namely the obligation to report and be caught red-handed.

a. Mandatory report (self-awareness). 
Mandatory reporting is an activity of self-reporting carried out by narcotics addicts who are old enough or their families, and / or parents or guardians of narcotics addicts who are not old enough to receive recipient institutions to report to get treatment and / or care through medical rehabilitation and social rehabilitation. This mandatory reporting activity is carried out by addicts, families and guardians voluntarily, on the basis of the desire to recover.

b. Caught in the hands (through a judge's decision, entrusted by a prosecutor and investigator)

Joint Regulation on Handling Narcotics Addicts and Narcotics Abuse Victims into Rehabilitation Institutions.

The implementation of medical rehabilitation for addicts, abusers, and victims of narcotics abuse who are undergoing the process of investigation, prosecution and trials as well as addicts, abusers, and victims of narcotics abuse who have received judgments or court decisions is regulated in Minister of Health Regulation Number 80 of 2014.

Medical rehabilitation procedures for addicts, abusers, and victims of narcotics abuse who are undergoing a process of investigation, prosecution and trial based on Minister of Health Regulation Number 80 of 2014.

Furthermore, the procedure for handing over addicts, abusers, and victims of narcotics abuse who have obtained a decision on court decisions into rehabilitation facilities is:

a. Addicts, Abusers, and Narcotics Abuse Victims who have obtained a ruling or court decision that has permanent legal force to undergo treatment and/or care through rehabilitation, are handed over by the prosecutor to a designated medical rehabilitation facility and an official appointment/court decision is signed by the officer prosecutor, the patient concerned and health personnel who receive the patient, by attaching:

1) copy/excerpt of a court decision letter or a court decision letter that has permanent legal force; and

2) letter of statement of the ability of the patient to carry out medical rehabilitation in accordance with the therapeutic plan stipulated by the Doctor team from the Integrated Assessment Team and to follow the applicable program at the intended rehabilitation institution. This statement of commitment must be signed by the patient and family/guardian.

3) Submission made to the Administrative Office of appointed house.

4) The implementation of a medical rehabilitation program is based on the determination/decision of the court and adapts to the applicable program at the intended medical rehabilitation institution

Management of rehabilitation of medical addicts, abusers and victims of narcotics abuse who have received a court ruling or decision. In general, addicts, abusers, and narcotics abuse victims who have received judgments/judicial decisions must follow the applicable program at the medical rehabilitation institution, together with the program for drug addicts and narcotics abusers who come on their own/family (voluntary). This is to ensure the implementation of the program consistently and give the effect of positive behavior changes that are not discriminatory.

While undergoing medical rehabilitation, addicts, abusers and Narcotics Abuse victims who have been decided by the court are not allowed to communicate directly or indirectly with the family for approximately 1 (one) month, in order to minimize undesirable things, such as conspiring with families to put narcotics into rehabilitation institutions, planning forced return, manipulating families for various purposes. Addicts can communicate with their family after undergoing the program for more than 1 (one) month, as stated in a rule applied in the rehabilitating institution. In the event needed for legal related purposes, addicts, abusers and 
narcotics abuse victims can communicate with other parties outside the family while undergoing rehabilitation, with the permission of the family.

Rehabilitation of narcotics abuse is basically an effort to cure and eliminate the dependence of victims of narcotics abuse. The rehabilitation process is divided into 2 (two) stages, namely medical rehabilitation and social rehabilitation, plus Post-rehabilitation/after-care stage.

Medical rehabilitation is a process of integrated medical activities to free addicts from drug addiction. Medical rehabilitation is carried out on narcotics abusers who have experienced a very high level of narcotics dependence. The dependence is marked by the urge to use narcotics continuously with increasing doses to produce the same effect. If stopped, it will cause bipsychological symptoms for the addict. This medical rehabilitation is an attempt to eliminate the dependence of an addict on narcotics.

Social rehabilitation is an integrated process of recovery activities, both physical, mental and social, so that former narcotics addicts can return to carry out social functions in people's lives. Social rehabilitation is carried out by rehabilitation institutions formed by the provincial national narcotics agency (BNNP) and some are established based on the community who want to establish a rehabilitation institution. This community rehabilitation agency is under the supervision of the provincial national narcotics agency, social services, and also the health department. In this place of rehabilitation, addicts undergo various programs including therapeutic communities (TC), 12 steps (twelve steps), religious approaches,

Furthermore, in relation to place of rehabilitation, as mandated in article 54 of Law Number 35 of 2009 concerning Narcotics, narcotics addicts must undergo medical rehabilitation and social rehabilitation. The place of rehabilitation must meet the standards set by the minister of health for medical rehabilitation and the social minister for social rehabilitation. Medical rehabilitation and social rehabilitation are carried out in medical rehabilitation facilities and social rehabilitation organized by the government, local government or the community.

3.2 Efforts to Build Prevention of Narcotics Circulation in Detention Centers for Security and Order in Prison

Efforts and Countermeasures in Preventing Narcotics Smuggling In Cirebon Class I Prisoners and Based on the results of the author's interviews with several people related to the author's title, the following are countermeasures to prevent narcotics smuggling in the Cirebon Class I Prison:

a. Maximizing Search

The main gate or the front gate of the prison is suspected to be an opportunity for the entry of drugs in prisons. As public know, the prison security system is still not equipped with adequate facilities and infrastructure. Therefore, a maximum search of visitors to prisons is carried out. Inspection of luggage and visitor data collection are examples of efforts made by prison officials. special fines will be carried out to not only prison visitors, but also each prisoner, if they are suspected of having drugs in prisons.

The effort is made because if it is returned to the factor that many prison staffs are lack of knowledge about drugs and unavailability of detection equipment, then drug dealers who want to bring drugs into prison will try various ways to hide these drugs. For example, by hiding drugs in underwears, which is not manually checked or searched. The weakness of this search process is often used by irresponsible parties such as drug dealers and prisoners who need drugs. Often prison officials are unaware with this way.

Something similar must be done to prisoners. Sudden inspections must be held to check the existence of narcotics in prisons. 
Preventive actions also stipulate the existence of inspection that is carried out every 3 months in collaboration with the police. ${ }^{14}$

1) Improve facilities and infrastructure as well as the quality of human resources prison Staff. The lack of facilities and infrastructure greatly affect the quality of prison officers so that it has become a factor in the occurrence of drug trafficking in prisons. Therefore, it is necessary to increase the facilities and infrastructure of prison staff in order to improve the quality of HR in prisons. Some examples are by providing drug detection equipment and debriefing on drug knowledge to prison officers.

2) Coaching prisoners

Correctional Institutions are a place for fostering prisoners before they return to society and live a good life and do not repeat the crimes. Regarding to the problem of drug trafficking in prisons, fostering prisoners who have been involved in drug problems will play a major role in efforts to restore prisoners back to their nature in human relations with their Lord, human beings with their personalities, human beings with each other, and humans and their environment. Based on the analysis of the author, in addition to provide a deterrent effect, prison is a place to guide prisoners. The aim is to restore prisoners to be good citizens and protect the public against the possibility of repeated crimes by inmates. In the correctional system, prisoners have the right to receive spiritual and physical formations, and their rights are guaranteed. To implement it, community participation is also needed, either by holding cooperation in coaching or by willing to accept returning prisoners who have finished serving their prisoners.

\section{b. Enforcement Efforts}

The countermeasures carried out by prosecution are efforts made by law enforcement officials in the form of imposition or granting criminal sanctions to perpetrators of crime, in this case carried out by the police, prosecutors, courts and penal institutions ${ }^{15}$. Repressive actions must be in accordance with established procedures and on the orders of the highest superiors of the police. The action must get an order from the boss because if there is a procedural error resulted in a loss for the perpetrator or the community, this is the responsibility of the supervisor. It means officials who work in the field in carrying out actions are not arbitrary ${ }^{16}$. These actions can be in the form of paralysis of the perpetrators, making arrests, investigations, inquiries and so forth. The police make repressive efforts in the form of sudden inspection carried out three times each year. Correctional Institutions provide guidance to prisoners in the form of mental religious guidance, legal counseling and various kinds of skills

Apparatus Correctional Institutions in preventing drug trafficking in prisons, here are the obstacles and obstacles faced by the Cirebon Class I Prison.

1) Facilities and infrastructure

In general, facilities and infrastructure are supporting tools for the success of efforts carried out in public services, because if both of these are available, all activities will be able to achieve the expected results as a plan. Likewise with facilities and infrastructure in prisons are needed to support everything that the prisoners themselves want to achieve. The lack of facilities and infrastructure, both in quality and quantity, greatly influences the circulation in prisons especially the quality of the facilities and infrastructure must follow technological

14 Lamintang, P.A.F. (1997). Dasar-Dasar Hukum Pidana Indonesia. Bandung: Citra Aditya Bakti, p. 23.

15 Ilyas, A. and Widaningsih, Y. (2010). Hukum Korporasi Rumah sakit. Yogyakarta: Rangkang Education, p. 66.

16 Hamzah. A. (1987). Stelsel Pidana dan Pemidanaan di Indonesia, Jakarta, Aksara Baru, p. 43. 
developments. From the results of the author's interview, the lack of facilities and infrastructure such as the unavailability of detection equipment made the security system in prisons less optimal.As known that drug trafficking in prisons is carried out clandestinely, then "certain parties" take the opportunity. The main door to the prison is suspected to be an opportunity for the entry of drugs. But with the lack of facilities and infrastructure such as this detector device, the drugs will easily enter the prison. Therefore, one of the obstacles to the Cirebon Class I Detention Center is the lack or absence of facilities and infrastructure to detect narcotics in the Cirebon Class I Prison.

\section{2) Quality of Human Resources Officer in Detention Center}

As we know, HR stands for Human Resources. The quality of human resources in prison officials relates to facilities and infrastructure in prison. Due to lack of facilities and infrastructures available in prisons, the quality of the prison staff's human resources also contributed to the occurrence of narcotics smuggling in the Cirebon Class I Prison. This happens because not all officials can recognize the types and forms of narcotics. The prison officials only carry out standard checks such as checking visitors' luggage and writing visitors' identity manually. The process can be said to be minimal to be applied in the Cirebon Class I Prison.

The author's analysis of the results of interviews about the factors underlying the occurrence of drug trafficking in the Cirebon Class I Prison, namely:

First about the facilities and infrastructure. In general, facilities and infrastructure are tools for the success of effort carried out in public services, ${ }^{17}$ because if these two things are not available then all activities carried out cannot achieve the expected results according to the plan. Means are all types of equipment, work equipment and facilities that function as the main tools or auxiliary tools in carrying out work, and also in the framework of interests related to work organizations. In the Cirebon Class I Prison, cases of narcotics smuggling are very $b$ various ways done by the end to smuggle narcotics. The most difficult thing to detect is by inserting narcotics into a beauty device. And various types of smuggling are more difficult to express. Therefore, narcotics detectors are very necessary to help prison officials in preventing smuggling in the Cirebon Class I Prison.

Then the second is the problem of the quality of human resources in prison officials. The quality of the personnel of this apparatus is also inseparable from the role of facilities and infrastructure in prisons. In general, the procurement of facilities and infrastructure with the quality of human resources in prison officials is very related. The quality of prison officials will increase with the support of good facilities and infrastructure. However, despite the availability of facilities and infrastructure such as sophisticated detectors, while the quality of human resources officers in prison is still low, it still will not break the access to drug trafficking in prisons. There must be an effort to improve the quality of the quality of human resources in prison officials.

According to the author, besides giving training on knowledge about types of narcotics, the officers who succeed in the meniscus prison or arrest drug smugglers should be awarded or promoted. This will stimulate prison officials to be more enthusiastic in combating drug smuggling in the Cirebon Class I Prison.

The research findings on the legal system for the prevention of narcotics circulation are as follows:

a. Prevention of Narcotics Circulation in Cirebon Class I Prison

Some findings of conditions in the field related to the narcotics distribution prevention system are:

${ }_{17}$ Amirin, Tatang, M, (1986). Pokok-Pokok Teori Sistem. Jakarta: CV. Rajawali. 
1) Metal Detectors

The results showed that in the Cirebon Class I Prison there were $60 \%$ metal detectors that were not good and $40 \%$ were good metal detectors. This is very worrying, because $40 \%$ of respondents agreed, and it must be taken seriously. Broken metal detectors must be repaired or replaced with new ones.

2) CCTVs

The results showed that in the Cirebon Class I Prison there were $20 \%$ in bad condition and $80 \%$ CCTVs in good condition. This is very worrying, and must be taken seriously. Bad or broken CCTVs must be repaired or replaced with a new one.

3) Sniffer Dog

In the Cirebon Class I Detention Center no sniffer dogs were available. The police do not use tracking dogs to detect narcotics. For this reason, it should be considered to provide narcotics tracking dogs.

4) Sterilization Room

The results of the study showed that in Cipinang Class I Prison there were $20 \%$ less good Sterilization Rooms and $80 \%$ good Sterilization Rooms. For this reason, we need to consider the availability of sterilization rooms, the functions of the sterilization room, and the use of sterilization rooms

5) Human Resources Professionalism

$\mathrm{HR}$ at the Cipinang Class I Correctional Institution must be upgraded to professionalism.

6) Visitor

in Cirebon Class I Prison, visitors who are examined less tightly had the potential to smuggle narcotics.

b. Prevention of Narcotics Circulation in Cirebon Class I Prison

Legal culture is an attitude and values related with behavior. Say no to drug! This is a slogan that is very simple but has complex implications related to expectations that must be realized, the business and its policies must be implemented. Say no to drugs, is not only a jargon, this is the responsibility of the nation's component to improve and empower the community towards a healthy life from mental, physical, and spiritual aspects. Around the world, many programs have been established with the intention to prevent Narcotics abuse, or to treat those who are affected by narcotics through certain religious beliefs and practices. This approach is mostly carried out in Indonesia and other developing countries. In the west, religion is not so prominent in preventing drug abuse, but we believe that religious-based programs really have a concern in that direction.

The finding of the research on the legal culture is that in the Cirebon Class I Prison the number of visitors in the cultured category is bad. From this finding, even though there are many visitors with good culture, there are still bad visitors. This is quite worrying, considering that visitors who are cultured are not good enough to worry about influencing visitors with good culture. Certainly not something that is excessive if it is then said that there is an opportunity that $20 \%$ of all visitors are less good culture.

The results of the study show that the Cirebon Class I Prison is still inhabited by prisoners and detainees. This indicates that there are inadequate Detention Center (Lapas) and even overlaps. The function of Detention Center (Lapas) is a place to carry 
out the fostering of prisoners and detainees. For this reason, it should be separated between prisoners and detainees.

c. Legal Substance to prevent drug trafficking in Cirebon Class I Prison

The meaning of legal substance is a rule or norm. The circulation of drugs in Indonesia initially only used for medical treatment, but the meaning has expanded as the time changes. Drugs are not used for medical treatment but also consumed by certain people, or we can say drug abuses. In the end the circulation of abused drugs is called the circulation of narcotics in which there is drug trafficking. Circulation of narcotics is at a level of concern for the Indonesian people, where narcotics circulation has now begun to be youthful and children. This of course must get serious handling by the government, in 1997 the government began to seriously make the rule of law with the enactment of Law No. 22 of 1997 Narcotics and Law Number 5 of 1997 concerning Psychotropic, then revised to Law Number 35 of 2009 about Narcotics

Law Number 35 of 2009 concerning Narcotics when viewed from a legal positivist stream examined from the circulation of narcotics is categorized as harmful to health, the reality that occurs in the life of the narcotics circulation community must be an effort to prevent and prevent. The rule of positive law in the law will be more effective with the imposition of prison imprisonment; the flow of legal positivism also recognizes laws outside the law. In the sense of positivism law does not separate between existing or applicable (positive) law, with the law that should exist. Penalties for imprisonment for narcotics dealers have been appropriately implemented, for drug addicts should not be imprisoned but rehabilitated. Because it ignores what is behind the law, namely in the form of truth, welfare and justice values that should be in the law.

Article 1 Paragraph 6 of Law Number 35 of 2009 concerning Narcotics (Narcotics Law), illegal circulation of narcotics and narcotics precursors are any activities or series of activities carried out without rights or against the law which are defined as criminal acts of narcotics and narcotics precursors. Article 38 of the Narcotics Law further stipulates that every narcotics distribution activity must be completed with legal documents. Therefore, without legal documents, the circulation of narcotics and narcotics precursors is considered as illicit circulation. In order to create a deterrent effect on the perpetrators of illicit trafficking in narcotics and narcotics precursors, the Narcotics Law regulates the weighting of criminal sanctions, in the form of special minimum penalties, 20 (twenty) years imprisonment, life imprisonment, and capital punishment. The criminal charge is based on the class, type, size and number of narcotics. For drug traffickers, there are at least 6 articles in the Narcotics Law which are threatened with the death penalty. In the case of illicit drug trafficking in prisons, the criminal provisions in the Narcotics Law apply to both prisoners and prison officers who are proven to be involved.

Related to the circulation of narcotics in prisons, the consideration of Law No. 12 of $1995^{18}$ concerning Correctional Services (Penitentiary Law) states that the correctional system implemented in Lapas is a series of law enforcement aimed at making prisoners aware of their mistakes, correcting themselves, and not repeating criminal acts so that they can be accepted back by the community, can actively play a role in development, and can live naturally as good and responsible citizens. As a regulation for the implementation of the Correctional Services, Article 4 Paragraph 7 of Ministry Regulation of Law and Human Rights Number 6 of 2013 concerning the Rules of Correctional Institutions and State Detention Centers, the regulation prohibits every prisoner or detainee from storing, making, carrying, distributing, and/or consuming

${ }^{18}$ Law of the Republic of Indonesia Number 12 of 1995 concerning Correctional Services 
narcotics and/or narcotics precursors and other dangerous drugs. Violations of this prohibition including this prohibition include severe penalties provided for in Article 10 Paragraph (3). Whereas in the case of a violation committed by an inmate or detainee suspected of being a criminal act, Head of Prison or Head of Detention Center continues to the authorized agency (Article 17 of Ministry Regulation No. 6 of 2013) ${ }^{19}$

d. Narcotics Circulation Prevention System to Realize Justice for Peace

There is a glimmer of hope in efforts to realize justice for peace in detention center (Lapas) in the form of rehabilitation, methadone therapy, appreciation for officers and the formation of regulations. Efforts to realize justice for peace are carried out by the following actions:

1) Rehabilitation

Narcotics abuse mostly starts with trial and error in the social environment. The longer the usage, the higher the risk of addiction. If it continues, then the dose of narcotics used will also be greater to reach the desired condition. Up to the point of not being able to miss a day without narcotics. Some symptoms that indicate a person is already in the stage of addiction include the desire to consume narcotics every day or several times a day, the dose needed is getting bigger and bigger, the desire to use narcotics cannot be detained. Users also ensure that the supply of narcotics continues to be available and are willing to spend money only to buy narcotics and even steal for it

Therefore, narcotics rehabilitation is needed as an effort to save users from narcotics shackles. For that there are several stages of narcotics rehabilitation that need to be done. The key to narcotics rehabilitation is to do it as soon as possible. For this reason, a narcotic dependency specialist is needed with the help of a psychiatrist or counselor specialized in this field. Like other addicts, narcotics addicts often deny their conditions and are difficult to ask for rehabilitation. Usually intervention from family or friends is needed to motivate or make drug users want to carry out rehabilitation.

There are three stages of narcotics rehabilitation that must be undertaken. First, the stage of medical rehabilitation is the process of addicts stopping narcotics abuse under the supervision of a doctor to reduce withdrawal symptoms (sakau). The second stage, namely the stage of non-medical rehabilitation with various programs in rehabilitation places, such as therapeutic communities (TC), 12-step programs and others. Then the last stage is the advanced development stage which will provide activities according to interests and talents. In addition, addicts who have successfully passed this stage can return to the community, whether to go to school or return to work.

The process of breaking away from narcotics for its users is not easy. In addition to undergoing narcotics rehabilitation, they also need the support of family and society to be able to return to a healthy and productive life.

2) Methadone Therapy

The results showed that the alternative methadone therapy was carried out on several assisted residents. Methadone is provided in the Methadone Maintenance Therapy Program, a program that transfers heroin users to other safer drugs. Methadone is a synthetic opiate (narcotics) that is strong like heroin (putaw) or

19 Ministerial Regulation of the Ministry of Law and Human Rights Number 6 of 2013 concerning the Rules of Correctional Institutions and State Detention Houses 
morphine, but does not cause a strong sedative effect. Methadone is not a cure for opiate dependence. While using methadone, users remain dependent on physical opiates. But methadone offers users the opportunity to change their lives to be more stable and reduce the risks associated with injecting drug use, and also reduce the crimes often associated with addiction. And because it is drunk, the use of methadone reduces the use of syringes alternately,behavior that is very risky for transmitting HIV and other viruses. PTRM has two choices. The first goal is to help users stop using heroin, replaced with step-by-step methadone doses over a period of time. The second goal is to reduce some of the adverse effects of injecting heroin. This option provides maintenance therapy, which provides methadone to users continuously with a dose that is adjusted so that users do not experience drug withdrawal symptoms. The second goal is to reduce some of the adverse effects of injecting heroin.

The option provides maintenance therapy, which provides methadone to users continuously with a dose that is adjusted so that users do not experience drug withdrawal symptoms. The second goal is to reduce some of the adverse effects of injecting heroin. This option provides maintenance therapy, which provides methadone to users continuously with a dose that is adjusted so that users do not experience drug withdrawal symptoms. Methadone is given to program clients in the form of liquid (syrup solution) which is taken under the supervision of PTRM every day. Each client needs a different dose, due to differences in metabolism, weight and tolerance to opiates. Some time is needed to determine the right dose of methadone for each client. Initially, the client must be observed every day and the reaction to the dose is assessed. If the client shows signs or drug withdrawal symptoms, the dose must be increased. Generally the program starts at a dose of 20 $\mathrm{mg}$ of methadone and then increases by $5-10 \mathrm{mg}$ per day. Usually clients stay in therapy and are able to stop using heroin at moderate to high methadone doses (60100mg).

3) Reward

For officers who can disclose the circulation of narcotics at the Penasyrakatan institution, they should be given adequate rewards in the form of money, badges, not just certificates. Plans are needed because of the pride of the officers. Apart from that, officers who are witnesses of disclosure of drug trafficking in prisons should be provided with facilities to witness in the court, for example, transportation to and from court, food allowance.

Updates are contained in the Draft of Regulation of the Minister of Law and Human Rights concerning Prevention of Narcotics Circulation in Prisons and Detention Centers based on the results of the study. Prevention by Gilling made up of two elements, a prediction and intervention.

It can be said that to prevent the occurrence of something (crime), the first thing to do is to predict the possibility of the place and time of occurrence, and then apply the right intervention. At the estimated point $35^{20}$ The Security Unit is obliged to conduct a search of the body and the goods visited by the search of the body and visiting goods as referred to in Article 3 above, carefully and thoroughly, the Security Unit can cooperate with relevant agencies to assist in the search of bodies and items of visits. Activate and place the internal supervision task force in the P2U area specifically to conduct searches of bodies and goods against traffic officers in prisons or detention centers.

${ }^{20}$ Gilling, D. (2005). Crime Prevention: Theory, Policies and Politics. London \& New York: Routledge Taylor \& Francis Group, p. 2. 
Supervise officers who are reasonably suspected of being involved in the circulation of prohibited goods, and provide jobs that do not interact with prisoners/detainees. The minister can impose sanctions on assimilation supervisory officers if found to be assimilated inmates violating the rules of the Prison/Detention Center.

\section{Conclusion}

Based on the background of the problem and discussion as described above, a conclusion can be taken as follows the legal system for preventing drug trafficking in realizing justice for peace in prisons continues to be built. Circulation of narcotics in prisons is an impact of the loss of legal system control. This is indicated by the condition of the legal system in the form of legal structure, legal substance and legal culture which is very worrying, but there is still a glimmer of hope in realizing justice for peace in detention center (lapas) in the form of rehabilitation, methadone therapy, appreciation for officials and the formation of regulations. Therefore it is recommended that the Ministry of Law and Human Rights immediately need to improve the legal system, both legal structure, legal substance and legal culture.

Efforts and control of correctional institutions in preventing narcotics smuggling in the Cirebon Class I prison are through positive action that must be carried out by each element, and the most important thing is to do the handling of smuggling by the penitentiary, through direct action taken by law enforcement officers, namely police, prosecutors, courts, and prisons and constraints and constraints of correctional institutions in preventing narcotics smuggling in the Cirebon Class I prison are facilities and infrastructure and quality of prison personnel.

\section{Reference}

Books:

Amirin, Tatang, M, (1986). Pokok-Pokok Teori Sistem. Jakarta: CV. Rajawali.

Gilling, D. (2005). Crime Prevention: Theory, Policies and Politics. London \& New York: Routledge Taylor \& Francis Group.

Hamzah. A. (1987). Stelsel Pidana dan Pemidanaan di Indonesia, Jakarta, Aksara Baru.

Ilyas, A. and Widaningsih, Y. (2010). Hukum Korporasi Rumah Sakit. Yogyakarta: Rangkang Education.

Lamintang, P.A.F. (1997). Dasar-Dasar Hukum Pidana Indonesia. Bandung: Citra Aditya Bakti.

Mariani, Y.T. (2008). Pengantar Hukum Indonesia. Jilid 4. Jakarta: Sinar Grafika.

Purnamasari, A. (2013). Skripsi: Tinjauan Kriminologis Terhadap Tindak Pidana Peredaran Narkoba di dalam Lembaga Pemasyarakatan Klas I Kota Makassar, Makassar: Fakultas Hukum Universitas Hasanuddin.

Soekanto, S. and Mamudji, S. (2006). Penelitian Hukum Normatif. Jakarta: RajaGrafindo Persada.

Soesilo, R. (1996). Kitab Undang-undang Hukum Pidana (KUHP) serta Komentar-Komentarnya Lengkap Pasal demi Pasal. Bogor: Politeia.

Sujono, A.R. and Daniel, B. (2011). Comments \& Discussion on Law Number 35 of 2009 concerning Narcotics, Jakarta: Sinar Grafika.

\section{Regulations:}

Penal Code (KUHP)

Law of the Republic of Indonesia Number 35 of 2009 concerning Narcotics.

Law of the Republic of Indonesia Number 5 of 1997 concerning Psychotropics.

Law of the Republic of Indonesia Number 12 of 1995 concerning Correctional Services. 
Ministerial Regulation of the Ministry of Law and Human Rights Number M.HH-16.Kp.5.02. 2011 About the Code of Conduct for Correctional Staff.

Ministerial Regulation of the Ministry of Law and Human Rights Number 6 of 2013 concerning the Rules of Correctional Institutions and State Detention Houses.

\section{World Wide Web:}

http:// pedomanbengkulu.com/2016/03/50-peredarannarkotika-dikontrol-dari-lapas/, (accessed April 5, 2017).

http://www.seputar-indonesia.com

https://kabar24.bisnis.com/read/20190218/16/890332/peredaran-narkoba-di-lembagapemasyarakatan-signaled-strengthen

prison narcotics.wordpress.com /

www.bbc.co.uk/indonesia/130711_lapsus_korupsi_drugs.shtml. July 11, 2017 